\title{
EXPORTS, UNEMPLOYMENT AND THE WELFARE STATE
}

\author{
ECKHARD JANEBA
}

CESIFO WORKING PAPER NO. 1977

CATEgory 7: TRAdE POLICY

APRIL 2007

\footnotetext{
An electronic version of the paper may be downloaded

- from the SSRN website: $\quad$ www.SSRN.com

- from the RePEc website: $\quad$ www.RePEc.org

- from the CESifo website: www.CESifo-group.de
} 


\title{
EXPORTS, UNEMPLOYMENT AND THE WELFARE STATE
}

\begin{abstract}
The paper analyzes the labor market effects of globalization when foreign market entry is costly and risky. With flexible labor markets, a fall in foreign market entry cost tends to generate more income inequality. By contrast, when workers cannot easily switch industries and wages are inflexible in the short run, globalization tends to increase unemployment. In this situation, government unemployment benefits reduce the wages that exporting firm's need to pay workers as risk compensation. Thus more firms within an industry and more industries become exporters. The above findings are consistent with popular views about the globalization effects in the U.S. and continental Europe. The results also suggest that the welfare state can simultaneously cause an increase in unemployment and exports.
\end{abstract}

JEL Code: D40, F10, H20.

Keywords: income inequality, unemployment, exporters, beachhead cost, globalization.

\author{
Eckhard Janeba \\ Department of Economics \\ University of Mannheim \\ L7, 3-5 \\ 68131 Mannheim \\ Germany \\ janeba@ni-mannheim.de
}

March 30, 2007

I thank Ron Davies, my colleagues at Mannheim, and participants at CESifo 2006 and ETSG 2006 for helpful comments. All errors are mine. 


\section{Introduction}

A popular hypothesis holds that globalization has led to increasing income inequality in countries with flexible labor markets such as the U.S., but higher unemployment in those economies in which labor markets function sluggishly, in particular continental European countries such as Germany and France (a point also noted by Fisher, 2003). In this paper I develop a simple model with ex post heterogeneous firms which addresses the relationship between globalization and labor market outcomes. A key feature of the model is that exporting is a costly and risky activity. Before being able to sell abroad firms need to make a costly investment, sometimes called 'beachhead cost' (Baldwin 1988), such as expenditures for setup of a foreign distribution network or for compliance with local product regulation. Often these investments are sunk, as confirmed by Roberts and Tybout (1997), and need to be made before the ultimate success is known. For this reason not all firms within an industry enter the foreign market, a stylized fact supported by numerous studies (e.g., Bernard et al., 2003). The theoretical model presented below shows how a fall in beachhead cost (=globalization) has both intraindustry and interindustry effects in the export sector that ultimately translate into employment and wage outcomes, whose exact outcome depends on labor market institutions. ${ }^{1}$

As done previously, one could utilitize traditional Heckscher-Ohlin theory to understand the effect of globalization on labor market outcomes (more on this later). The present paper takes a different direction however. The modelling approach is in the spirit of but formally different and in some sense simpler than the more recent literature in international trade theory that stresses firm heterogeneity (e.g., Melitz, 2003, Baldwin, 2005) and its repercussion on wages (e.g. Yeaple, 2005), and therefore is able to identify exactly the channel through which exporting behavior feeds back to the domestic economy. In contrast to most of this literature, however, I allow for unemployment and thus labor market frictions. At a more general level, the paper is related to recent work on the nexus between firm-level output volatility and export or international orientation. For example, Fabbri, Haskel and Slaughter (2003) find that labor demand for less skilled labor has become more elastic for U.S. and U.K. manufacturing firms during a period in which multinational activity has increased. Buch, Döpke and Strotmann (2006) find that German exporting firms experience less volatility than domestic firms. They focus on macroeconomic shocks and do not explicitly distinguish between firms that enter foreign markets (and may fail) and those who export (and apparently succeeded.)

\footnotetext{
${ }^{1}$ I ignore the effects of globalization on the domestic labor market via import competition, but address the issue informally in section 5 .
} 
In this paper I show that in the presence of flexible labor markets globalization has no effect on unemployment and total labor income, but tends to increase income inequality between workers on the one hand and the residual claimants on firms' profits on the other hand. When the labor market is less flexible, however, globalization tends to lead to more unemployment (and perhaps also more inequality). The intuition for the case with flexible labor markets is that workers and wages adjust so that the distributional effect of globalization is solely transmitted via industry profits. There are three effects when beachhead costs fall: The direct effect on profits (for a given number of firms entering the foreign market) is positive, and thus leads to an increase in inequality. The other two effects are indirect ones, as the number of firms entering the foreign market changes. Industry profits decline because more firms pay the entry cost (the second effect). The third effect reflects the change in probability that foreign market rents are captured by either of the domestic firms (because of Bertrand competition between two successful exporters), and depends on the probability that any single firm is successful in foreign market entry. I provide sufficient conditions for economy wide profits to fall. Inequality increases when the success probability of foreign market entry takes rather extreme values.

Turning to the case with labor market rigidities, unemployment is not caused by a government mandated minimum wage, but rather it is the difficulty of reallocating labor across industries after the success of foreign market entry is realized, combined with little wage flexibility in the short run. An obvious reason for sectoral immobility of workers are sector-specific skills. Alternatively, industries may be located in different regions of a country and workers need to move to find a new job when released by an unsuccessful exporter. Empirically, workers in continental European countries are less prone to move than those in the U.S. ${ }^{2}$ When labor is immobile in the short run, wages could adjust to clear the labor market at the industry level. I assume, however, that wages are inflexible ex post. The inflexibility of wages in the short run conforms with anecdotal evidence related to the practice of firms downsizing in Europe.

A fall in beachhead cost drives unemployment. When the first firm in an industry finds entry into the foreign market profitable, unemployment in expected terms unambiguously increases. In equilibrium workers enter the industry until labor supply equals labor demand in the successful state (which happens with probability $q$ ), implying that with the probability of unsuccessful foreign market entry $(1-q)$ they become unemployed. As the

\footnotetext{
${ }^{2}$ Consistent with differential mobility is the difference in variation of regional unemployment rates between U.S. states on the one hand and German Länder on the other hand. The coefficient of variation for the former is 0.24 , but 0.36 for the latter (Jan. 2006 data). Also, the generous welfare benefits for unemployed workers in some continental European countries may reduce the incentive to find a new job.
} 
second firm enters the foreign market, two opposing effects occur. On the one hand, the probability of no firm being successful is smaller with two firms $(1-q)^{2}$ than with one firm $1-q$, pushing unemployment unambiguously down. On the other hand, the increase in product market competition when both firms are successful (which occurs with probability $q^{2}$ ) leads to higher expected output and industry labor demand, pulling more workers into the industry. I show that upon entry of the second firm industry unemployment increases if either the success probability is sufficiently small or the foreign economy is sufficiently large. The change in economy-wide unemployment is determined by the sum of the interindustry (i.e., industries entering the foreign market) and intraindustry effects (i.e., more firms within an exporting industry entering the foreign market). I show that overall unemployment rises when the country is sufficiently small relative to the rest of the world.

The case of short-run immobile labor and wages provides further interesting insights. Assuming that the government pays released workers unemployment benefits, there is an inverse relationship between the unemployment benefit and the wage offered by exporting firms. Workers need to be made indifferent between working in the secure numeraire sector and the risky export sector. The expected income for the latter option depends on how the government treats unemployed workers. Therefore, unemployment benefits allow exporting firms to pay less than in the absence of such government benefits (but still more than in the secure numeraire sector). The consequence is important: All else equal, a country with the higher unemployment benefit per worker has lower wages in the exporting sector, induces more firms within an industry to enter the foreign market and, when successful, to increase output due to lower cost. This pulls more workers into the industry, and additional industries to become exporting industries in the first place, which together generate more unemployment and welfare state expenditures in expected terms. ${ }^{3}$

The above result may explain some puzzling features about the German economy. German exports are booming, seemingly attesting to the competitiveness of the economy, while at the same time unemployment is significantly above the average of OECD countries. Going hand in hand with mass unemployment goes a generous welfare state, a large share of the government budget and overall economic output devoted to pay unemployed workers, finance early retirement packages for elderly people, and other costly labor mar-

\footnotetext{
${ }^{3}$ The result does not imply a strictly positive correlation between exports and welfare state expenditures because countries may differ in labor market flexibility. For the same reason the model does not contradict the empirical observation that wages of unskilled workers in continental Europe exceed those in the U.S.
} 
ket policies (see Sinn 2006). The present paper explains these features by arguing that the welfare state influences industry labor supply (and not only individual labor supply, as argued by Sinn, which in turn triggers firms to outsource unskilled labor intensive activity to low-wage countries) and provides incentives for firms to enter foreign markets when labor and wages are immobile in the short run.

Another implication of the analysis is that the generosity of the welfare state in the presence of short-run immobile labor and wages is here the cause to more unemployment, a bigger government sector, and more exports. This is in contrast to Rodrik (1998) who argues that the rising share of government expenditures in GDP in the face of globilization is the consequence of mitigating the increase in external risk - measured by the product of the openness of the economy and the volatility of the terms of trade.

Most of the existing work on globalization and labor markets utilizes variants of a traditional Heckscher-Ohlin framework. The increasing wage gap between skilled and unskilled workers can be rationalized by Stolper-Samuelson effects. Similarly, introducing a minimum wage in a country that trades freely with a flexible economy leads to unemployment in the former country, a point formally shown within a factor abundance approach by Brecher (1974), Chao and Yu (1997), and Davis (1998). Explaining both phenomena with the Heckscher-Ohlin (HO) theory is problematic, however, because either some assumptions or implications are in conflict with empirical observations (see Burtless et al. 1998 for a critical analysis of the empirical validity of various HO implications). Davis (1998) analyzes consequences of a minimum wage in an integrated world economy, where all countries are fully diversified in production. Factor price equalization holds and the wage of unskilled workers are equalized at the level of the minimum wage. This conflicts with the wide distribution of wages for unskilled workers across countries. In addition, diversified production of all countries appears at odds with the high degree of specialization observed in practice (see Schott (2003) for a detailed empirical analysis).

Three other approaches generating unemployment have been pursued. Matusz (1986) and Fernandez (1992) use the theory of implicit contracts to study wage formation and employment in an open economy. Unlike the present paper the welfare state is not considered explicitly. ${ }^{4}$ In Matusz (1996) unemployment is the result of paying efficiency wages. More intra-industry trade due to trade liberalization is shown to reduce unemployment however. Most recently, Kreickemeier and Nelson (2006) introduce an international trade

\footnotetext{
${ }^{4}$ This is partly so because the government is assumed to be restricted in the same way as firms to insure workers in bad states of the world. By contrast, I assume here the opposite which reflects the view that firms may not want to compensate workers in such situations if they know the government's concern and willingness to reduce income inequality.
} 
model with a fair wage constraint and show that unemployment arises endogenously.

The paper is structured as follows. In section 2 a model with flexible labor markets is introduced. In section 3 comparative statics with respect to beachhead cost are undertaken. In section 4 I consider the case with inflexible labor markets and the resulting link between exports, unemployment and the generosity of the welfare state. Section 5 concludes.

\section{The Model}

Consider an open economy which produces goods in two sectors with one input factor (labor). The $Z$ sector is characterized by constant returns to scale, where one unit of labor is transformed into one unit of output, and is the importing sector in equilibrium. The price of sector $Z$ output is normalized to one. The second sector, called $X$, consists of a continuum of industries and will be the export sector in equilibrium (as in a Ricardian type model). ${ }^{5}$ Industries differ in their productivity. The output of a firm in industry $i$ is

$$
x(i)=a(i) l(i)
$$

where $a(i)$ is the productivity parameter and $l(i)$ is the amount of labor used. Labor productivity $a$ is distributed continuously on some compact interval $[\underline{a}, \bar{a}]$ with constant density $m$. Thus there are many industries with identical productivity, but producing different goods.

In each industry there are many, ex ante symmetric firms producing a homogenous good and competing in prices (quantity competition is briefly reviewed in section 5). Each firm serves the domestic market, and in addition must decide whether to enter a foreign market. Foreign market entry is costly and requires spending sunk cost $F$, which are also called beachhead cost. Unlike variable trade cost like tariffs or transportation cost, the beachhead cost represent the cost of complying with local market regulations, setting up a sales network, etc. The success of foreign market entry is random however. With probability $q$ a firm is successful and serves the foreign market. With probability $1-q$, however, entry is unsuccessful and the firm is not in a position to sell in the foreign market. Since sunk cost $F$ are paid before the firm finds out about its success, entry is a decision under uncertainty. The probability of success is identical for each firm in each industry, and independent from firm to firm.

\footnotetext{
${ }^{5}$ One could introduce another sector $Y$, similar in structure to the $X$ sector, which is located in the rest of the world. In that case the home country imports output from $\mathrm{Y}$ industries in addition to or instead of importing the numeraire good.
} 
To simplify the analysis I focus on case with at most two firms entering the foreign market. If both firms enter the foreign market, with probability $q^{2}$ both firms are successful and compete in prices, leading to zero profits. With probability $2 q(1-q)$ one firm is successful, while the other is not, and with probability $(1-q)^{2}$ both firms are unsuccessful and do not export. Clearly, a firm can make strictly positive profits in the foreign market only if it is the only firm with a positive draw and is thus a monopolist. In addition, entering the foreign market requires that the additional expected profits cover the fixed cost $F$ of foreign market entry.

I now turn to the consumer side of the economy. There is a mass of $L$ identical individuals. Each worker supplies one unit of labor inelastically and consumes the numeraire good and all goods from the $X$ sector. Preferences are of the quadratic form

$$
u(x, z)=z+\int \alpha x(i)-\beta x(i)^{2} d i
$$

where $\alpha$ and $\beta$ are positive parameters. Consumption is financed through labor income. Given the structure of preferences profits from the $X$-sector could be distributed to households, which would show up in demand for the numeraire good only. Assuming that profits are accrued by separate owners (and who spend it on the numeraire good) allows me to address distributional issues, as globalization changes both labor income and profits. Individuals are equally productive across industries and thus there is a uniform wage when labor markets are flexible. Utility maximization implies that demand for any $x$ good is a linear function of its own price only, $x_{d}=x_{d}(p ; i)$. All income effects are subsumed into the demand for good $z$. Thus total demand for good $i$ is $X_{d}(p ; i)=L x_{d}(p ; i)$ given price $p$. I assume that foreign demand is generated from a similar demand structure, but allow countries to differ in size. Let foreign's labor force be $L^{*}=\lambda L$, where $\lambda>0$ is a scale parameter. Then foreign demand for home's exports of good $i$ is simply $X_{d}^{*}(p ; i)=\lambda X_{d}(p ; i)$ at any common price $p$.

I begin with an analysis of the case with flexible labor markets. The timing of events is as follows. In a first stage firms make their decison simultaneously about foreign market entry. If entering, a firm has to pay immediately the sunk cost. Then the success of those firms entering foreign markets is realized. Firms compete in prices and hire workers to produce goods, which are then sold to consumers who maximize utility by choosing consumption quantities given prices and lump sum profit income. There exists one national labor market and hence there is no unemployment. Any worker released by an unsuccessful firm can find work in the secure numeraire sector. There exists also a continuum of goods markets (one for each industry) and the market for good $Z$. Trade is balanced by Walras law. As mentioned above, the country necessarily exports sector $X$ output 
because the foreign country does not produce but values these goods.

For each industry of sector $X$ the game is solved backwards to determine the equilibrium entry and pricing decisions. In the domestic market the two firms are Bertrand competitors. In the foreign market there are zero, one or two firms competing after the entry success is determined. Since demand for the homogenous good depends only on own price, competition between two (successful) firms leads to marginal cost pricing, as in the domestic market. Profits are zero. The wage $w$ is given through sector $Z$ and equals one. Dropping the industry index for expositional convenience, the equilibrium price for an industry with two (successful) firms is

$$
p^{C}(c)=c=w / a=1 / a,
$$

where the superscript $C$ refers to competition and $c$ to marginal cost. When a firm is monopolist in the foreign market it charges the monopoly price $p^{M}(c)$, assuming that for all industries the monopoly price is less than the willingness to pay for the first unit of a good $\alpha$. Let $\pi$ denote the profit in the domestic market. The monopoly profit for a firm serving the foreign market is $\lambda \pi^{M}$ (because of the linearity of demand). When no firm is successful in entering the foreign market, exports and foreign consumption of the good are zero, the price is infinite (or above the consumers reservation price).

The above can be used to determine the expected profits at the foreign market entry stage of the game. Denote by $(i, j), i, j \in\{E, N\}$, the entry decisions of firm $i$ and $j$, where $E$ stands for entry into the foreign market and $N$ for no entry.

- When both firms do not enter the foreign market $(N, N)$, the expected total profit of all firms is zero, $\pi_{N N}=0$. Firms compete fiercly at home and the competitive price leads to zero profits from the domestic market.

- If one firm enters the foreign market, but the other does not, $(E, N)$ or $(N, E)$, the domestic firm (superscript $E$ ) obtains zero, $\pi_{E N}^{N}=0$. The exporting firm (superscript $E$ ) has expected profits of

$$
\pi_{E N}^{E}=q \lambda \pi^{M}-F
$$

The first term refers to the expected monopoly profit in the foreign market. There is no price arbitrage across markets possible. The value of $\pi_{E N}^{E}$ is positive when $F$ is sufficiently small, but is negative if not.

- When both firms enter the foreign market $(E, E)$, each firms expected profit is

$$
\pi_{E E}=q(1-q) \lambda \pi^{M}-F
$$


which may or may not be positive. The superscript $E$ is not used here because both firms are symmetric. Recall that $q(1-q)$ is the probability of being a monopolist in the foreign market.

Note that $\pi_{E N}^{E}>\pi_{E E}$, that is, the expected profit of the firm that exclusively enters the foreign market is greater than the expected profit of the firm when also the rival is a potential exporter. A summary of the firms' payoffs at the entry stage is given in Table 1.

\begin{tabular}{|c|c|c|}
\hline $\begin{array}{ll} & \text { Firm } 2 \\
\text { Firm } 1 & \end{array}$ & $E$ & $N$ \\
\hline$E$ & $\begin{array}{l}q(1-q) \lambda \pi^{M}-F \\
q(1-q) \lambda \pi^{M}-F\end{array}$ & $q \lambda \pi^{M}-F$ \\
\hline$N$ & $q \lambda \pi^{M}-F$ & 0 \\
\hline
\end{tabular}

Table 1

The next step is to identify the equilibria of the entry game. It is easy to see that $(N, N)$ is an equilibrium of the entry game if $\pi_{E N}^{E}<0$ or $q \lambda \pi^{M}<F$, which simply states that beachhead cost exceed the expected monopoly profit in the foreign market. Both firms entering is an equilibrium if $\pi_{E E}>0$, which is equivalent to $q(1-q) \lambda \pi^{M} \geq F$. Here the beachhead cost must be sufficiently small because the probability of being a monopolist is now only $q(1-q)$. Finally, the situation with only one firm entering $(E, N)$ or $(N, E)$ is an equilibrium if $\pi_{E N}^{E}>0>\pi_{E E}$, that is, $q(1-q) \lambda \pi^{M}<F \leq q \lambda \pi^{M}$. The following result follows now immediately, as for each level of beachhead cost there is only one equilibrium in the entry game.

Proposition 1. The pure-strategy equilibrium in the foreign market entry game leads to a unique number of firms in an industry entering the foreign market, given beachhead cost $F$ and industry productivity $a$.

Of course, when the equilibrium outcome involves only one firm entering the foreign market it is not determined which of the two firms it is. Given symmetry, however, this aspect is of no interest for all results derived further below. Overall, the structure of the model is fairly simple and as is shown in the next section shares properties with other trade models with heterogeneous firms. 


\section{Globalization with Flexible Labor Markets}

In this section I do comparative statics with respect to the beachhead cost and thus with the number of firms entering the foreign market. A fall in $F$ can be interpreted as globalization. For any particular industry with productivity $a$, equilibrium values of important variables change only at two critical points of $F$, namely when fixed cost equal expected profits of the first and second firm entering the foreign market, i.e., $F_{1}=q \lambda \pi^{M}(a)$ and $F_{2}=q(1-q) \lambda \pi^{M}(a)$. Alternatively, for a given level of sunk cost $F$ there exist industries with productivity levels $a_{1}$ and $a_{2}$ such that a firm breaks even when entering the foreign market alone or jointly, that is $F=q \lambda \pi^{M}\left(a_{2}\right)$ and $F=q(1-q) \lambda \pi^{M}\left(a_{1}\right)$.

Analyzing the effects of globalization on equilibrium price, profits, and export volume is of interest to check the plausibility of the model. The model is fairly consistent with other models of trade with heterogenous firms (see Melitz, 2003, and Baldwin 2005).

Proposition 2. a) The mass of industries entering the foreign market increases when $F$ falls. b) Expected industry exports (weakly) increase when $F$ falls. c) Conditional on exports taking place, the expected export price in an industry decreases and the variance of the price increases when the number of firms entering the foreign market increases from one to two.

The first result is straightforward given Proposition 1. For given productivity $a$, there exists a critical threshold level of the fixed entry cost, which makes an industry an exporting one by inducing the first firm to enter the foreign market. Monopoly profit $\pi^{M}(a)$ is increasing in productivity $a$. When productivity is continuously distributed, a fall in $F$ has the predicted consequence. Result b) is easy to prove as exports are zero under $(N, N)$, while expected exports equal $q X_{d}^{*}\left(p^{M}\right)$ for the case of one firm entering the foreign market. The export volume is even higher when both firms enter the foreign market $(E, E)$ because expected exports amount to

$$
q^{2} X_{d}^{*}\left(p^{C}\right)+2 q(1-q) X_{d}^{*}\left(p^{M}\right)=q\left[q\left(X_{d}^{*}\left(p^{C}\right)-X_{d}^{*}\left(p^{M}\right)\right)+(1-q) X_{d}^{*}\left(p^{M}\right)\right]+q X_{d}^{*}\left(p^{M}\right),
$$

which is clearly higher than $q X_{d}^{*}\left(p^{M}\right)$. The reasons are twofold. Exports are higher when both firms succesfully enter the foreign market since price competition stimulates demand. In addition, the probability of unsuccessful foreign market entry falls from $1-q$ to $(1-q)^{2}{ }^{6}$

\footnotetext{
${ }^{6}$ Result 1 applies to aggregate exports of an industry. Interestingly, the result does not necessarily hold for an individual firm, even if we condition on that firm being an exporter. For example, comparing the case of $(E, N)$ and $(E, E)$ the expected exports of a firm that is entering the foreign market in both situations is unchanged if one assumes that the firms split the market when both successful. Of course, this is the consequence of the linear demand structure which implies that the monopoly output is half of the competitive output.
} 
Concerning part c), a single successful firm charges the monopoly price. The expected price is thus the monopoly price and its variance is zero (conditional on exports occurring). By contrast, when both firms enter, with probability $q^{2}$ the two firms end up charging a price equal to marginal cost, while with probability $2 q(1-q)$ the firm with the good draw charges the monopoly price. Thus, conditional on exports taking place, the expected price is now lower and has positive variance. I now turn to characterizing profits as function of fixed cost.

Proposition 3. Assume that at least one firm enters the foreign market. A fall in $F$ increases expected industry profits holding fixed the number of firms entering the foreign market. Expected industry profits drop discontinuously, however, when entry cost fall below the critical level at which the second firm enters the foreign market, $F=$ $q(1-q) \lambda \pi^{M}$.

The proof is straightforward. The industry profit level corresponding to one and two firms entering the foreign market is given by

$$
\begin{aligned}
\pi_{E N}^{E} & =q \lambda \pi^{M}-F \text { and } \\
2 \pi_{E E} & =2\left[q(1-q) \lambda \pi^{M}-F\right]
\end{aligned}
$$

respectively. The latter is less than the former when the two expressions are evaluated at $F=q(1-q) \lambda \pi^{M}$, which is the critical level at which the second firm finds entry profitable. Figure 1 graphs industry profits as a function of beachhead cost.

Proposition 3 suggests an interesting trade off for economic inequality. As $F$ falls, more industries enter foreign markets and the number of industries with multiple firms changes.

Proposition 4. Economy wide expected profits increase when $F$ falls if the probability of foreign market success is sufficiently small or sufficiently large. In those cases globalization leads to an increase in the country's total income but an increasing gap between labor income and expected profits. 
Industry profits

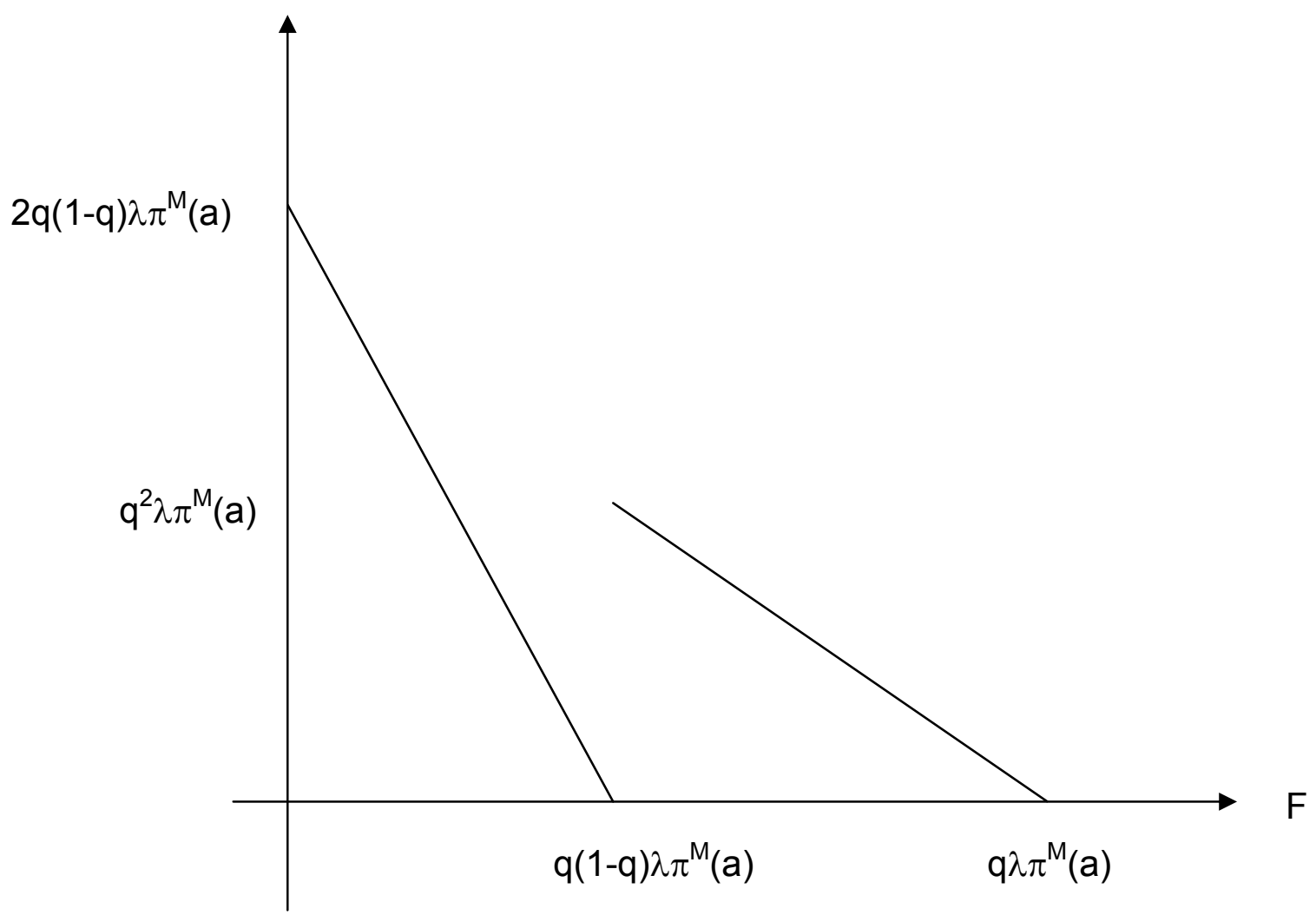

Figure 1 - Industry profits for given productivity 
The proof for this result requires defining aggregate profits

$$
\Pi=m \cdot\left[\int_{a_{1}}^{\bar{a}} 2 \pi_{E E} d a+\int_{a_{2}}^{a_{1}} \pi_{E N}^{E} d a\right]
$$

where $m$ is the mass of industries at any given productivity level, $a_{1}$ and $a_{2}$ are the critical productivity values at which the number of firms changes, given fixed cost $F$. They are implicitly defined by $q(1-q) \lambda \pi^{M}\left(a_{1}\right)=F$ and $q \lambda \pi^{M}\left(a_{2}\right)=F$, respectively. Differentiating with respect to $F$ the change in economy wide profits equals

$$
\begin{aligned}
\frac{d \Pi}{d F} & =m\left[\left(a_{1}+a_{2}-2 \bar{a}\right)+\frac{d a_{1}}{d F}\left(F+\lambda \pi^{M}\left(a_{1}\right)[q(1-2(1-q))]\right)+\frac{d a_{2}}{d F}\left(F-q \lambda \pi^{M}\left(a_{2}\right)\right)\right] \\
& =m\left[\left(a_{1}+a_{2}-2 \bar{a}\right)+\left(\frac{d a_{1}}{d F} \frac{F q}{1-q}\right)\right]=m\left[a_{1}\left(1+\frac{\epsilon q}{1-q}\right)+a_{2}-2 \bar{a}\right]
\end{aligned}
$$

where the second equality is explained further below. The first term within the square brackets, $a_{1}+a_{2}-2 \bar{a}$, is always negative and reflects the direct effect of an increase in $F$, that is, the increase in expenditures on fixed costs holding constant the number of firms entering the foreign market. The second term is the indirect effect and depends on the mass of industries switching the number of firms in the foreign market,

$$
\frac{d a_{1}}{d F}=\frac{1}{\lambda q(1-q)\left(\partial \pi^{M} / \partial a_{1}\right)}=\frac{\pi^{M}}{\partial \pi^{M} / \partial a_{1}}>0 .
$$

The indirect effect in (4) has two components: (i) the reduction in fixed costs when one firm is no longer entering the foreign market and (ii) the change in probability of having a monopoly in the foreign market from $2 q(1-q)$ to $q$. The last term in the first line of (4) is zero by definition of $a_{2}$.

In general the net effect of an increase in sunk cost on industry profits is ambiguous. The direct effect dominates however when $q$ takes extreme values. To see this, the change in industry profit can be written as in the second line of (4) by subsituting out $\lambda \pi^{M}\left(a_{1}\right)=$ $F / q(1-q)$ and collecting terms. When the success probability is small, the threshold levels $a_{1}$ and $a_{2}$ become very similar $(q \approx q(1-q))$, and the indirect effect vanishes because for given $F$ and $a_{1}$ there exist many combinations of $q$ and $\lambda$ that leave $a_{1}$ unchanged. Hence, as $q$ becomes very small (and $\lambda$ adjusts), the derivative (5) stays unchanged, but the indirect effect becomes small.

By contrast, when the success probability is close to 1 , in almost no industry both firms enter the foreign market, that is $a_{1}$ is very large, but $a_{2}$ is close to $\underline{a}^{7}$ In the

\footnotetext{
${ }^{7}$ The term $\epsilon q /(1-q)$ does not explode because the elasticity goes to zero as the success probability goes to one.
} 
limit, $a_{1}$ exceeds $\bar{a}$, and thus the indirect effect vanishes again. The second statement in Proposition 4 follows immediately now because the economy's labor income is independent of the degree of internationalization. The wage rate equals one and labor supply is fixed.

In summary, when labor markets are flexible the model is consistent both with some implications derived in other recent trade models and with the rising inequality in AngloSaxon countries over the last quarter century. The results should not be overinterpreted, of course, as the model ignores some important aspects (discussed in section 5 in more detail). Rather the contribution of the analysis is to model explicitly how the riskiness of foreign market entry feeds back into the domestic economy.

\section{Globalization with Short-Run Immobile Labor and Wages}

In the previous section it was assumed that the labor market is completely flexible and workers are perfect substitutes across industries. All workers are employed after foreign entry success materializes and the wage is uniform across sectors and industries. In this section I take a different perspective: Workers cannot easily switch jobs across industries and sectors ex post. Instead workers must decide in which industry/sector to work before the firms' foreign market entry success is revealed. They become unemployed if not hired by firms in the industry for which they opted. The assumption is reasonable if industries are geographically dispersed and workers do not move easily, as is much more the case in continental Europe than in the U.S. Workers can opt to work in sector $Z$ though (before uncertainty is revealed), which guarantees an income of one because the sector faces no risk. Workers are risk-neutral since all income effects enter the consumption of the numeraire good due to the constant marginal utility of consuming $z$.

Even with short run immobile labor unemployment is not an automatic consequence however. If labor demand falls short of industry labor supply, the market would clear when wages fall sufficiently. I assume, however, that this is not the case. One reason could be that flexibility makes wages more volatile, which following Azariadis' (1975) theory of implicit contracts, induces risk averse workers to trade off employment security for income security. Here I follow a similar idea (without formally modelling it). A firm offers a specific wage and hires workers. The promise to pay the wage is enforceable when the firm's labor demand is not less than its initial hiring, given product market competition and foreign market entry success. By contrast, when less workers are needed, the firm randomizes among its existing workers. The firm's excess labor supply can be 
hired by other firms in the same industry at their wage, which happens only if such firms find themselves in a labor shortage situation. When the latter does not happen the worker becomes unemployed and receives government unemployment benefit $b \in[0,1)$, and thus less than the wage in the numeraire sector. I do not model explicitly the government sector here. It may be assumed, however, that government spending is financed by a lump sum tax on workers, which affects only demand for the numeraire good.

The timing of the game is as follows: 1) Firms decide whether to enter foreign market, 2 ) each firm sets a wage, 3) workers choose to work for a particular firm in industry $i$ in sector $X$ or in sector $Z, 4$ ) foreign market entry success is resolved, and 5) production, consumption and trade take place. Note that wages typically depend on the entry strategy of both firms. For this reason I examine each entry pair separately.

\section{Case $(\mathbf{N}, \mathbf{N})$}

Both firms do not enter the foreign market. Profits are deterministic and the wage is one $\left(w_{N N}=1\right)$. There is no unemployment.

\section{Case $(\mathrm{E}, \mathbf{N}) /(\mathbf{N}, \mathbf{E})$}

Workers hiring with the exporting firm face stochastic income. To compensate them, they must be offered a wage $w_{E N}^{E}$ higher than their outside option of one. The superscript $E$ in the wage term refers to the wage of the firm entering the foreign market. Given the higher wage, the firm loses in price competition in the domestic market with the non-exporting firm if the latter hires workers at a wage of one. The non-exporting firm's labor demand is deterministic and given by

$$
L_{d}^{N}=\frac{X_{d}\left(p^{*}\right)}{a}, \text { where } p^{*}=\min \left\{c_{E N}^{E}, p^{M}\left(c_{E N}^{N}\right)\right\} .
$$

In words, labor demand depends on sales in the domestic market where the price charged is the smaller of the marginal cost of the exporting firm, $c_{E N}^{E}=w_{E N}^{E} / a$, and the monopoly price, given that the non-exporting firm pays workers a wage of unity, and thus $c_{E N}^{N}=1 / a$.

The firm entering the foreign market thus produces output only for exports if its entry is successful. Suppose that the firm hires as many workers as necessary to serve the foreign market in case entry is successful, that is,

$$
L_{d}^{E}=\frac{\lambda X_{d}\left(p^{M}\left(c_{E N}^{E}\right)\right)}{a} .
$$

Then each worker gets the wage $w_{E N}^{E}$ with probability $q$, and faces unemployment with probability $1-q$, in which case he is paid $b$ by the government. To attract workers the expected income must equal the outside option of working in sector $Z$. The wage of the 
$E$ firm must therefore satisfy

$$
w_{E N}^{E}=\frac{1-(1-q) b}{q}>1
$$

Note that now all equilibrium conditions are satisfied. Each risk-neutral worker obtains an expected income of one and wages set by firms maximize expected profits. If the exporting firm offered a lower wage, nobody would want to work for the firm. Paying more lowers profits strictly. The exporting and non-exporting firm's profits are $\pi_{E N}^{E}=q \lambda \pi^{M}\left(c_{E N}^{E}\right)-F$ and $\pi_{E N}^{N}=\left(p^{*}-1 / a\right) X_{d}\left(p^{*}\right)$. Expected unemployment in this case is

$$
U_{E N}=(1-q) L_{s}=\frac{(1-q) \lambda X_{d}\left(p^{M}\left(c_{E N}^{E}\right)\right)}{a},
$$

where $c_{E N}^{E}=w_{E N}^{E} / a$.

Case (E,E)

The entry strategy is symmetric and I therefore focus on symmetric equilibrium in terms of the wage paid $w_{E E}$. Instead of deriving the equilibrium step by step, I propose the following equilibrium allocation: Industry labor supply is

$$
L_{s}=\frac{X_{d}\left(p^{C}\right)}{a}+\frac{\left.\lambda X_{d}\left(p^{M}\right)\right)}{a},
$$

where each firm hires one half of $L_{S}$. Notice the superscripts on prices in (9). Assume for a moment that the wage is sufficiently high so that exactly $L_{S}$ workers enter the industry. With probability $(1-q)^{2}$ both firms are unsuccessful and all firms compete only in the domestic market. In this situation labor supply exceeds labor demand by the second factor in (9). With probability $2 q(1-q)$ one firm is successful and the other is not, leading to industry labor demand equal to industry labor supply. There is no unemployment because workers can switch from the unsuccessful firm to the successful firm at the same wage. Finally, when both firms are successful in foreign market entry, they compete in Bertrand fashion at home and abroad. Labor demand exceeds labor supply in this case (at marginal cost pricing labor demand in foreign is higher), but there is no pressure to bid up wages since profits are zero for both firms. All workers are employed.

The last step is to determine the wage consistent with entry of $L_{s}$ workers. To find the wage, the expected income of a worker must equal one, that is,

$$
\left[q^{2}+2 q(1-q)+(1-q)^{2} \frac{X_{d}\left(p^{C}\left(c_{E E}\right)\right)}{a L_{s}}\right] w_{E E}+(1-q)^{2}\left[1-\frac{X_{d}\left(p^{C}\left(c_{E E}\right)\right)}{a L_{s}}\right] b=1 .
$$

The first two terms in the first square bracket refer to the cases where either one or both firms are successful and thus industry labor demand equals or exceeds industry labor 
supply, and thus each worker earns $w_{E E}$. But even when both firms are unsuccessful, some workers earn $w_{E E}$ because the domestic market is served. A worker's employment probability is equal to the ratio of industry labor demand to industry labor supply. One minus the employment probability is the likelihood of being unemployed, in which case the worker receives $b$. This is the second term in (10). Expression (10) can be simplified by inserting (9) and using the fact that under the linear demand structure the monopoly output equals half the competitive output. Hence

$$
w_{E E}=\frac{2+\lambda\left(1-(1-q)^{2} b\right)}{2+\lambda q(2-q)},
$$

which is greater than one if $q \in(0,1)$. Expected profits equal $\pi_{E E}=q(1-q) \lambda \pi^{M}\left(c_{E E}\right)-F$. Expected industry unemployment in that industry is

$$
U_{E E}=\frac{(1-q)^{2} \lambda X_{d}\left(p^{M}\left(c_{E E}\right)\right)}{a},
$$

where $c_{E E}=w_{E E} / a$. Unemployment occurs only when both firms are unsuccessful.

\begin{tabular}{|l|c|c|}
\hline $\begin{array}{c}\text { Firm 2 } \\
\text { Firm 1 }\end{array}$ & $E$ & $N$ \\
\hline \multirow{2}{*}{$E$} & $q(1-q) \lambda \pi^{M}\left(c_{E E}\right)-F$ & $\left(p^{*}-c_{E N}^{N}\right) X\left(p^{*}\right)$ \\
& $q(1-q) \lambda \pi^{M}\left(c_{E E}\right)-F$ & $q \lambda \pi^{M}\left(c_{E N}^{E}\right)-F$ \\
\hline$N$ & $q \lambda \pi^{M}\left(c_{E N}^{E}\right)-F$ & 0 \\
& $\left(p^{*}-c_{E N}^{N}\right) X\left(p^{*}\right)$ & 0 \\
\hline
\end{tabular}

Table 2

I now turn to the analysis of equilibrium entry strategies given fixed cost and industry productivity. Table 2 provides a summary of the profits at the entry stage. The outcome in the entry game is not necessarily as clear cut as in the case with flexible labor markets because the wages are dependent on entry strategies. The pair $(E, E)$ is an equilibrium if sunk cost are sufficiently small, that is $\pi_{E E}>\pi_{E N}^{N}$

$$
F<q(1-q) \lambda \pi^{M}\left(c_{E E}\right)-\left(p^{*}-\frac{1}{a}\right) X_{d}\left(p^{*}\right) .
$$

Foreign market entry of exactly one firm $((E, N),(N, E))$ occurs if $\pi_{E N}^{E}>\pi_{N N}$ and $\pi_{E N}^{N}>\pi_{E E}$, or

$$
q(1-q) \lambda \pi^{M}\left(c_{E E}\right)-\left(p^{*}-\frac{1}{a}\right) X_{d}\left(p^{*}\right)<F<q \lambda \pi^{M}\left(c_{E N}^{E}\right) .
$$


Such a fixed cost range may not exist because marginal cost $c_{E N}^{E}$ are typically higher than $c_{E E}$, as shown below, and hence the monopoly profit in the $(E, N)$ case, $\pi_{E N}^{M}$, may be smaller than in the $(E, E)$ case, $\pi_{E E}^{M}$. I shall assume, however, that for each industry there exists a sunk cost level such that $(E, N)$ is an equilibrium for intermediate levels of foreign market entry cost. Armed with this assumption comparative statics with respect to $F$ can be carried out.

Specifically, I analyze unemployment levels when within an industry the number of firms entering the foreign market increases. Clearly, unemployment goes up when moving from $(N, N)$, where unemployment is zero, to $(E, N)$ or $(N, E)$, where unemployment is given by (8). Less obvious is the effect when the second firm enters, i.e. a comparison of (8) and (12). On the one hand unemployment tends to be smaller because the probability of unsuccessful entry with two firms, $(1-q)^{2}$, is smaller than with one firm, $(1-q)$. On the other hand, the higher success probability of actually serving foreign consumers implies that the marginal cost in the case $(E, E)$ is lower, and hence foreign sales are higher, which in turn draws more workers into the industry. This point is easily seen by establishing

$$
w_{E N}^{E}-w_{E E}=(1-q)(1-b)(2+\lambda q)>0,
$$

and thus $c_{E N}^{E}>c_{E E}$ for given productivity.

The change in unemployment when the second firms enters is thus

$$
U_{E E}-U_{E N}=\frac{(1-q) \lambda}{a}\left[(1-q) X_{d}\left(p^{M}\left(c_{E E}\right)\right)-X_{d}\left(p^{M}\left(c_{E N}^{E}\right)\right)\right] .
$$

Unemployment increases in the number of firms entering the foreign market if the first term in square brackets is sufficiently large relative to the second term (in absolute value). This is the case when $q$ is sufficiently close to zero because the monopoly price is an increasing function of the unit cost and thus $X_{d}\left(p^{M}\left(c_{E E}\right)\right)>X_{d}\left(p^{M}\left(c_{E N}^{E}\right)\right)$. Alternatively, the wage and thus the marginal cost differential in (13) is substantial when the foreign country is large relative to the home country, that is, (13) is increasing in $\lambda$.

Proposition 5. When workers and wages are inflexible in the short run, a rise in the number of firms entering the foreign market due to globalization leads to an increase in industry unemployment and government expenditures for unemployment benefits if either foreign market success $q$ is sufficiently small or the rest of the world $\lambda$ is sufficiently large.

The intuition is straightforward. Globalization leads to a larger market and more output per firm for a given wage. As beachhead costs drop, more and more workers are 
drawn into the export sector because the probability of unsuccessful entry with two firms is smaller than with one.

The analysis can be taken a step further when analyzing economy wide unemployment. As foreign market entry cost fall, more industries become exporters, and thus unemployment tends to increase. Formally, economy-wide unemployment is

$$
U=m \cdot\left[\int_{a_{1}}^{\bar{a}} U_{E E}(a) d a+\int_{a_{2}}^{a_{1}} U_{E N}(a) d a+\int_{\underline{a}}^{a_{2}} U_{N N}(a) d a\right],
$$

where the last integral is zero (non-exporting industries). Unemployment depends on marginal cost of exporting firms which in turn is a function of wages and productivity. Differentiating with respect to fixed cost and rearranging gives

$$
\frac{d U}{d F}=m\left[\left[U_{E N}\left(a_{1}\right)-U_{E E}\left(a_{1}\right)\right] \frac{d a_{1}}{d F}-U_{E N}\left(a_{2}\right) \frac{d a_{2}}{d F}\right] .
$$

The treshold levels $a_{1}$ and $a_{2}$ are both increasing in $F$. Thus unemployment falls for rising $F$ when the foreign country is sufficiently large, because in that case $U_{E N}\left(a_{1}\right)<U_{E E}\left(a_{1}\right)$. Yet, even when the difference is slightly positive, an overall fall in unemployment is likely as unemployment is reduced by those industries exiting foreign markets (i.e., the last term in (16)).

Another important insight comes from considering the role of the welfare state. An increase in the unemployment benefit $b$ leads to a proportional increase in welfare state spending holding industry labor supply constant. The change in $b$, however, triggers via wage effects also responses in exporting behaviour, and thus labor demand, which in turn tend to produce even larger increases in government expenditures.

Proposition 6. An increase in the unemployment benefit $b$ lowers the wage in firms entering the foreign market and raises industry labor supply. Government expenditures for unemployment benefits rise more than proportional, assuming the conditions for Proposition 5 hold.

Formally, this can be seen from differentiating government expenditures

$$
G=b U=b m\left[\int_{a_{1}}^{\bar{a}} U_{E E}(a) d a+\int_{a_{2}}^{a_{1}} U_{E N}(a) d a\right],
$$

which gives

$$
\begin{aligned}
\frac{d G}{d b}= & U+b m\left[-\left(U_{E E}\left(a_{1}\right)-U_{E N}\left(a_{1}\right)\right) \frac{d a_{1}}{d b}-U_{E N}\left(a_{2}\right) \frac{d a_{2}}{d b}\right. \\
& \left.+\int_{a_{1}}^{\bar{a}} \frac{d U_{E E}(a)}{d b} d a+\int_{a_{2}}^{a_{1}} \frac{d U_{E N}(a)}{d b} d a\right]
\end{aligned}
$$


The threshold levels $a_{1}$ and $a_{2}$ are inversely related to $b$, which follows from (7) and (11). An increase in unemployment benefits allows firms to pay workers a smaller risk premium, holding foreign entry cost and other parameters constant. For the same reason unemployment is positively related to $b$. Lower wages mean a smaller monopoly price, more goods demand and an increase in industry labor demand. Thus overall government expenditures increase by more than the initial unemployment level.

So far I focused on the effects of globalization on unemployment rather than inequality. Before looking at inequality between profits and wages, it is interesting to note that in the presence of inflexible wages and immobile labor workers are no longer identical ex post. While all workers receive an expected income of one, the realized income is either higher or lower than one when a worker hires with a firm that enters the foreign market. In the present model workers are assumed to be risk-neutral and thus do not care about the increase in income volatility. Still, consistent with Rodrik (1998) globalization leads to an increase in external risk that makes incomes more volatile. Similar to the case with flexible labor markets and wages, inequality between expected labor income and profits increases when the first firm enters the foreign market compared to both firms staying domestic. Whether inequality increases even further when the second firm enters the foreign market is not clear a priori.

\section{Discussion}

This paper has developed a simple model of ex post hetergeneous firms which compete for foreign market rents. Stochastic productivity and foreign market entry cost determine the equilibrium number of firms entering the foreign market. The model is fairly tractable and could be used in applied contexts such as to study free entry of firms or the role of firm effort in relation to firm productivity. In the following I discuss two critical assumptions and an additional implication.

Firms produce a homogenous good and are assumed to compete in price. This leads to Bertrand competition whenever two firms are successful and thus face the same marginal cost. The advantage of this framework is that the analysis is fairly straightforward. A firm is either a monopolist or makes zero profits (except for the case with inflexible labor markets where limit pricing may occur). Assuming quantity competition in an otherwise identical model is likely to generate similar results. Competition between two successful firms is softened unter Cournot type competition, yet profits may not be large enough to justify foreign market entry of one or more than one firm.

The trade structure was assumed to be simple in order to focus on the effects of foreign 
market entry risk on domestic labor markets. The foreign country exports to the domestic economy either the numeraire good, which is not subject to stochastic entry success, or another good (say $y$ ) that is not produced at home. Thereby globalization has no effect on the domestic economy via import competition. The setting can be extended to address the issue however. It is not clear how in this new setting globalization affects inequality and unemployment. Even when the import competing firms face no own uncertainty, their product and thus labor demand is indirectly affected by foreign firms subject to their export market risk. At the same time domestic firms have smaller market shares when entry costs fall and thus reduce the number of workers in the import competing sector in the first place.

The model has further implications that go beyond the question raised in the present paper. For example, when workers are risk averse, they would tend to avoid export sectors. To the extent that workers can influence the degree of their own intersectoral mobility, they would try to reduce the risk of being stuck in any particular sector. How could they do this? Intersectoral mobility is often tied to the amount of general skills relative to sector-specific skills. The model therefore suggests that in economies with less flexible labor markets individuals invest more in general rather than specific skills. Moreover, given that specific skills are often more relevant for innovation we may expect that the risk of foreign market entry may spill over into the degree of innovation in an economy. 


\section{References}

Azariadis (1975): Implicit Contracts and Underemployment Equilibria, Journal of Political Economy 83, 1183-1202.

Baldwin, R. (1988): Hysteresis in Import Prices: The Beachhead Effect, American Economic Review 78, 773-785.

Baldwin, R. (2005): Heterogeneous firms and trade: testable and untestable properties of the Melitz model, NBER Working Paper 11471.

Bernard, A., Eaton, J., Jensen, J.B. and S. Kortum (2003): Plants and productivity in international trade, American Economic Review 93, 1268-1290.

Brecher, R.A. (1974): Minimum Wage Rates and the Pure Theory of International Trade, Quarterly Journal of Economics 88, 98-116.

Buch, C., Döpke, J., and H. Strotmann (2006): Does Export Openness Increase Firm-Level Volatility, mimeo., University of Tübingen.

Burtless, G., Lawrence, R.Z., Litan, R. E. and R.J. Shapiro (1998): Globaphobia: Confronting fears about open trade, Brookings Institution, Washington, D.C.

Chao, C.-C. and E.S.H. Yu (1997): Trade liberalization in oligopolistic competition with unemployment: A general equilibrium analysis, Canadian Journal of Economics 30, 479-496.

Davis, D. (1998): Does European Unemployment Prop up American Wages? National Labor Markets and Global Trade, American Economic Review 88, 478-494.

Fabbri, F., Haskel, J., and M.J. Slaughter (2003): Does Nationality of Ownership matter for Labor Demands?, Journal of the European Economic Association 1 (2/3), 698-707.

Fernandez, R. (1992): Terms-of-trade uncertainty, incomplete markets and unemployment, International Economic Review 33, 881-894.

Fisher, S. (2003): Globalization and its challenges, American Economic Review Papers and Proceedings, 93, May, 1-30.

Kreickemeier, U. and D. Nelson (2006): Fair wages, unemployment and technological change in a global economy, Journal of International Economics 70, 451-469.

Matusz, S.J. (1986): Implicit contracts, unemployment and international trade, Economic Journal 96, 307-322.

Matusz, S.J. (1996): International trade, the division of labor, and unemployment, International Economic Review 37, 71-84.

Melitz, M. (2003): The impact of trade on intraindustry reallocations and aggregate industry productivity, Econometrica 71, 1695-1725. 
Roberts, M.J: and J.R. Tybout (1997): The decision to export in Colombia: An empirical model of entry with sunk costs, American Economic Review 87, 545-564.

Rodrik, D. (1998): Why do more open governments have bigger governments?, Journal of Political Economy 106, 997-1032.

Schott, P.K. (2003): One size fits all? Heckscher-Ohlin specialization in global production, American Economic Review 93, 686-708.

Sinn, H.-W. (2006): The Pathological Export Boom and the Bazaar Effect: How to Solve the German Puzzle, The World Economy, 1157-1175.

Yeaple, S. (2005): A simple model of firm heterogeneity, international trade and wages, Journal of International Economics 65, 1-20. 


\section{CESifo Working Paper Series}

(for full list see www.cesifo-group.de)

1912 Bernard M. S. van Praag, Perspectives from the Happiness Literature and the Role of New Instruments for Policy Analysis, February 2007

1913 Volker Grossmann and Thomas M. Steger, Growth, Development, and Technological Change, February 2007

1914 Margarita Katsimi and Thomas Moutos, Human Capital and the Feldstein-Horioka Puzzle, February 2007

1915 Oliver Roehn, Theo S. Eicher and Thomas Strobel, The Ifo Industry Growth Accounting Database, February 2007

1916 Ian Babetskii, Aggregate Wage Flexibility in Selected New EU Member States, February 2007

1917 Burkhard Heer, Alfred Maussner and Paul D. McNelis, The Money-Age Distribution: Empirical Facts and Limited Monetary Models, February 2007

1918 Yin-Wong Cheung, Menzie D. Chinn and Eijii Fujii, The Overvaluation of Renminbi Undervaluation, February 2007

1919 Jim Malley, Apostolis Philippopoulos and Ulrich Woitek, To React or Not? Fiscal Policy, Volatility and Welfare in the EU-3, February 2007

1920 Mattias Polborn, Competing for Recognition through Public Good Provision, February 2007

1921 Lars P. Feld and Benno Torgler, Tax Morale after the Reunification of Germany: Results from a Quasi-Natural Experiment, February 2007

1922 Robert S. Chirinko and Huntley Schaller, Fundamentals, Misvaluation, and Investment: The Real Story, February 2007

1923 Benno Torgler and Friedrich Schneider, Shadow Economy, Tax Morale, Governance and Institutional Quality: A Panel Analysis, February 2007

1924 Adrian Pagan and M. Hashem Pesaran, On Econometric Analysis of Structural Systems with Permanent and Transitory Shocks and Exogenous Variables, February 2007

1925 Hans-Werner Sinn, The Welfare State and the Forces of Globalization, February 2007

1926 Michael Smart, Raising Taxes through Equalization, February 2007

1927 Øystein Foros, Kåre P. Hagen and Hans Jarle Kind, Price-Dependent Profit Sharing as an Escape from the Bertrand Paradox, February 2007 
1928 Balázs Égert, Kirsten Lommatzsch and Amina Lahrèche-Révil, Real Exchange Rates in Small Open OECD and Transition Economies: Comparing Apples with Oranges?, February 2007

1929 Aleksander Berentsen and Cyril Monnet, Monetary Policy in a Channel System, February 2007

1930 Wolfgang Ochel, The Free Movement of Inactive Citizens in the EU - A Challenge for the European Welfare State?, February 2007

1931 James K. Hammitt and Nicolas Treich, Statistical vs. Identified Lives in Benefit-Cost Analysis, February 2007

1932 Wilhelm Kohler, The Bazaar Effect, Unbundling of Comparative Advantage, and Migration, February 2007

1933 Karsten Staehr, Fiscal Policies and Business Cycles in an Enlarged Euro Area, February 2007

1934 Michele Bernasconi and Paola Profeta, Redistribution or Education? The Political Economy of the Social Race, March 2007

1935 Axel Dreher, Martin Gassebner and Lars-H. R. Siemers, Does Terror Threaten Human Rights? Evidence from Panel Data, March 2007

1936 Naércio Aquino Menezes Filho and Marc-Andreas Muendler, Labor Reallocation in Response to Trade Reform, March 2007

1937 Gebhard Flaig and Timo Wollmershaeuser, Does the Euro-zone Diverge? A Stress Indicator for Analyzing Trends and Cycles in Real GDP and Inflation, March 2007

1938 Michael Funke and Michael Paetz, Environmental Policy Under Model Uncertainty: A Robust Optimal Control Approach, March 2007

1939 Byeongchan Seong, Sung K. Ahn and Peter A. Zadrozny, Cointegration Analysis with Mixed-Frequency Data, March 2007

1940 Monika Bütler and Michel André Maréchal, Framing Effects in Political Decision Making: Evidence from a Natural Voting Experiment, March 2007

1941 Giacomo Corneo and Olivier Jeanne, A Theory of Tolerance, March 2007

1942 Qing Hong and Michael Smart, In Praise of Tax Havens: International Tax Planning and Foreign Direct Investment, March 2007

1943 Yin-Wong Cheung, Dickson Tam and Matthew S. Yiu, Does the Chinese Interest Rate Follow the US Interest Rate?, March 2007

1944 Panu Poutvaara and Mikael Priks, Unemployment and Gang Crime: Could Prosperity Backfire?, March 2007 
1945 Burkhard Heer, On the Modeling of the Income Distribution Business Cycle Dynamics, March 2007

1946 Christoph A. Schaltegger and Lars P. Feld, Are Fiscal Adjustments less Successful in Decentralized Governments?, March 2007

1947 Giovanni Facchini, Marcelo Olarreaga, Peri Silva and Gerald Willmann, Substitutability and Protectionism: Latin America's Trade Policy and Imports from China and India, March 2007

1948 C. Mirjam van Praag and Bernard M. S. van Praag, The Benefits of Being Economics Professor A (and not Z), March 2007

1949 Astrid Hopfensitz and Frans van Winden, Dynamic Choice, Independence and Emotions, March 2007

1950 Guglielmo Maria Caporale and Luis A. Gil-Alana, A Multivariate Long-Memory Model with Structural Breaks, March 2007

1951 Mattias Ganslandt and Keith E. Maskus, Wholesale Price Discrimination and Parallel Imports, March 2007

1952 Michela Redoano, Fiscal Interactions Among European Countries. Does the EU Matter?, March 2007

1953 Stefan C. Wolter, Rémy Hübschi and Matthias Müller, Push or Pull? An Empirical Analysis of the Demand for Individual Project Grants from the Swiss National Science Foundation, March 2007

1954 Scott Alan Carson, African-American and White Inequality in the American South: Evidence from the $19^{\text {th }}$ Century Missouri State Prison, March 2007

1955 Peter Egger, Marko Koethenbuerger and Michael Smart, Do Fiscal Transfers Alleviate Business Tax Competition? Evidence from Germany, March 2007

1956 Panu Poutvaara and Lars-H. R. Siemers, Smoking and Social Interaction, March 2007

1957 Stephan Danninger and Fred Joutz, What Explains Germany's Rebounding Export Market Share?, March 2007

1958 Stefan Krasa and Mattias Polborn, Majority-efficiency and Competition-efficiency in a Binary Policy Model, March 2007

1959 Thiess Buettner and Georg Wamser, Intercompany Loans and Profit Shifting Evidence from Company-Level Data, March 2007

1960 Per Pettersson-Lidbom and Mikael Priks, Behavior under Social Pressure: Empty Italian Stadiums and Referee Bias, April 2007 
1961 Balázs Égert and Carol S. Leonard, Dutch Disease Scare in Kazakhstan: Is it real?, April 2007

1962 Paul De Grauwe and Pablo Rovira Kaltwasser, Modeling Optimism and Pessimism in the Foreign Exchange Market, April 2007

1963 Volker Grossmann and Thomas M. Steger, Anti-Competitive Conduct, In-House R\&D, and Growth, April 2007

1964 Steven Brakman and Charles van Marrewijk, It’s a Big World After All, April 2007

1965 Mauro Ghinamo, Paolo M. Panteghini and Federico Revelli, FDI Determination and Corporate Tax Competition in a Volatile World, April 2007

1966 Inés Macho-Stadler and David Pérez-Castrillo, Optimal Monitoring to Implement Clean Technologies when Pollution is Random, April 2007

1967 Thomas Eichner and Ruediger Pethig, Efficient $\mathrm{CO}_{2}$ Emissions Control with National Emissions Taxes and International Emissions Trading, April 2007

1968 Michela Redoano, Does Centralization Affect the Number and Size of Lobbies?, April 2007

1969 Christian Gollier, Intergenerational Risk-Sharing and Risk-Taking of a Pension Fund, April 2007

1970 Swapan K. Bhattacharya and Biswa N. Bhattacharyay, Gains and Losses of India-China Trade Cooperation - a Gravity Model Impact Analysis, April 2007

1971 Gerhard Illing, Financial Stability and Monetary Policy - A Framework, April 2007

1972 Rainald Borck and Matthias Wrede, Commuting Subsidies with two Transport Modes, April 2007

1973 Frederick van der Ploeg, Prudent Budgetary Policy: Political Economy of Precautionary Taxation, April 2007

1974 Ben J. Heijdra and Ward E. Romp, Retirement, Pensions, and Ageing, April 2007

1975 Scott Alan Carson, Health during Industrialization: Evidence from the $19^{\text {th }}$ Century Pennsylvania State Prison System, April 2007

1976 Andreas Haufler and Ian Wooton, Competition for Firms in an Oligopolistic Industry: Do Firms or Countries Have to Pay?, April 2007

1977 Eckhard Janeba, Exports, Unemployment and the Welfare State, April 2007 